\title{
Structure of a 3D frame-bridge NiTi sample deposited on a low carbon steel substrate by wire arc additive manufacturing
}

\author{
N. N. Resnina ${ }^{\dagger, 1}$, I. A. Palani², P.S. Liulchak ${ }^{1}$, S. P. Belyaev', S. S. Mani Prabu², \\ S. Jayachandran ${ }^{2}$, V.D. Kalganov ${ }^{1}$ \\ †resnat@mail.ru

\begin{abstract}
${ }^{1}$ Saint Petersburg State University, 7/9 Universitetskaya Emb., St. Petersburg, 199034, Russia
${ }^{2}$ Discipline of Mechanical Engineering, Indian Institute of Technology Indore, Indore, 453552, India
\end{abstract}

\begin{abstract}
A 3D frame-bridge sample was produced by wire arc additive manufacturing (WAAM) on a low carbon steel substrate using the $\mathrm{Ni}_{50.9} \mathrm{Ti}_{49.1}$ shape memory wire with a diameter of $1.2 \mathrm{~mm}$. The sample consisted of a rectangular frame and three bridges. The structure and chemical composition were studied in different zones: the frame, the bridge or joint of the frame and the bridge using light and scanning electron microscopy with energy dispersive X-ray spectroscopy. It was shown that the structure of the frame and the bridge located far from the joint was close to the "walls" produced by WAAM: a columnar grain grew across the layers and the equiaxed grains appeared on the top of the layer. The structure of the joint between frame and bridge significantly differed from the "walls": from the frame side, columnar grains were found across and alone the layers, whereas, from the bridge side the columnar gains were observed in the first layer only. The study of the chemical composition showed that the Fe and $\mathrm{C}$ elements diffused to the sample from the low carbon steel substrate. As a result, TiC precipitates appeared in all layers that led to the alloy hardening. Fe atoms penetrated to the NiTi phase that suppressed the martensitic transformation.
\end{abstract}

Keywords: additive manufacturing, NiTi shape memory alloy, microstructure, wire arc additive manufacturing, 3D structure.

УДК: 669-1

\section{Структура 3D образца типа «рамка-мост» сплава NiTi,} наплавленного на низкоуглеродистую подложку методом электродуговой послойной наплавки

\author{
Реснина Н.Н. ${ }^{\dagger, 1}$, Палани И. А. ${ }^{2}$, Люльчак П. С. ${ }^{1}$, Беляев С. П. ${ }^{1}$, Мани Прабу С. С. ${ }^{2}$, \\ Джайячандран С. ${ }^{2}$, Калганов В. Д. ${ }^{1}$ \\ ${ }^{1}$ Санкт-Петербургский государственный университет, Университетская наб., 7/9, С.-Петербург, 199034, Россия \\ ${ }^{2}$ Отделение машиностроения, Индийский технологический институт Индора, Индор, 453552, Индия
}

3D образец типа «рамка-мост» был получен методом электродуговой послойной наплавки проволоки сплава с памятью формы $\mathrm{Ni}_{50.9} \mathrm{Ti}_{49.1}$ диаметром 1.2 мм на подложку из низкоуглеродистой стали. Трехслойный образец состоял и прямоугольной рамки и трех мостиков. Методами оптической и сканирующей электронной микроскопии с использованием метода энергодисперсионной рентгеновской спектроскопии исследовали структуру и химический состав в слоях трех различных зон: рамки, мостика и стыка рамки с мостиком. Показано, что структура рамки и мостика вдали от стыка близка к структуре «стенок», получаемых методом электродуговой послойной наплавки: столбчатые зерна растут поперек слоев, а на свободной поверхности верхнего слоя образуются равноосные зерна. Структура стыка между рамкой и мостиком существенно отличается от структуры «стенок»: со стороны рамки столбчатые зерна растут как поперек слоя, так и вдоль него. Со стороны мостика столбчатые зерна обнаружены только в первом слое. Исследование химического состава слоев показало, что железо и углерод попадают из подложки в расплав TiNi. Это приводит к образованию карбида титана во всех слоях, что упрочняет сплав. Внедрение атомов железа в фазу NiTi полностью подавляет мартенситные переходы.

Ключевые слова: аддитивные технологии, сплав с памятью формы NiTi, микроструктура, электродуговая послойная наплавка, 3D структура. 


\section{Introduction}

The production of complex shaped alloy components by additive manufacturing (AM) technologies becomes more intensive [1-3]. This allows one to fabricate samples which can not be obtained by traditional methods or makes such production simpler. The AM technologies include bed deposition or direct deposition technologies, which differ by the feedstock or heating source types [1-2].

The main attraction of AM is the fabrication of products (components, structures) from materials which are hardly subjected to mechanical treatment, for instance NiTibased shape memory alloys. NiTi-based products are very promising for industrial and biomedical applications due to the demonstration of the shape memory effect (strain recovery on heating of a pre-deformed sample), superelasticity (strain recovery on unloading), recovery stress (on heating of predeformed samples under fixed strain), reveal good corrosion resistance and biocompatibility [4-5].

In biomedical applications, NiTi-based shape memory alloys are used as dense or porous implants, as part of some medical instruments etc. [6-7]. For this purpose, NiTi-based elements are successfully produced by selective laser melting [8]. In this method, NiTi powder is used as a feedstock, however, strict requirements to powder should be provided to obtain samples with good properties [8-10]. This increases the cost of the product, and this technology is more applicable for the production of small elements, which is typical for biomedical applications.

For some industrial applications, for instance in dampers, large components of NiTi shape memory alloys are used, but in this case selective laser melting is not effective. At the same time, wire arc additive manufacturing (WAAM), which is one of the direct deposition technologies, can be used [11]. In this technique, the NiTi wire is used as a feedstock that significantly decreases the products cost. Moreover, WAAM allows producing large elements with a high productivity rate. This method is successfully applied for the production of massive samples from Ti-based, steels, Cu-based and other materials [11] and some attempts have been carried out to produce NiTi elements within the last two years [12-13].

As WAAM method is new for the deposition of the NiTi alloy, all produced samples were simple "walls" where the NiTi wire was deposited layer by layer in one line [12-13]. The study of the NiTi "walls" structure showed that the formation of grains in the NiTi sample was the same as in the "walls" deposited from other materials [11-13]. The structure of the first layer significantly differed from the feedstock material for two reasons: changing the chemical composition due to the partial remelting of the substrate and the formation of specific grain structure because a massive substrate provided high heat absorption that increases the solidification rate. The second and further layers consisted of large columnar grains that grew across the layers due to the epitaxial grain growth [10]. On the top of the last layer the equiaxed grain zone was formed [11].

At the same time, the sample with a complex shape can not be always produced by the deposition of the "wall". In this case, some junctions or connections of the deposited layers can exist and the conditions of heat dissipation for these volumes would differ from the conditions for the layers during the "wall" production. This may significantly affect the grain formation and influence the properties of the sample. Therefore, the aim of the present paper is the deposition of a 3D frame-bridge sample which consists of the frame and three bridges by WAAM using the $\mathrm{Ni}_{50.9} \mathrm{Ti}_{49.1}$ shape memory wire and a low carbon steel substrate and to study the structure of the sample in different parts.

\section{Methodology}

A 3D frame-bridge sample of NiTi alloys was deposited on a low carbon iron substrate $(10 \mathrm{~mm}$ thick) by the gas metal arc welding technology (voltage of $17.3 \mathrm{~V}$, wire feed rate of $4.3 \mathrm{~m} / \mathrm{min}$, shielding Argon gas rate of 15 litre/min) which was one of the WAAM modifications. The $\mathrm{Ni}_{50.9} \mathrm{Ti}_{49,1}$ wire with a diameter of $1.2 \mathrm{~mm}$ was used as a a feedstock. Fig. 1 presents the scheme of the NiTi wire deposition during the production of 3D frame-bridge sample. A rectangular

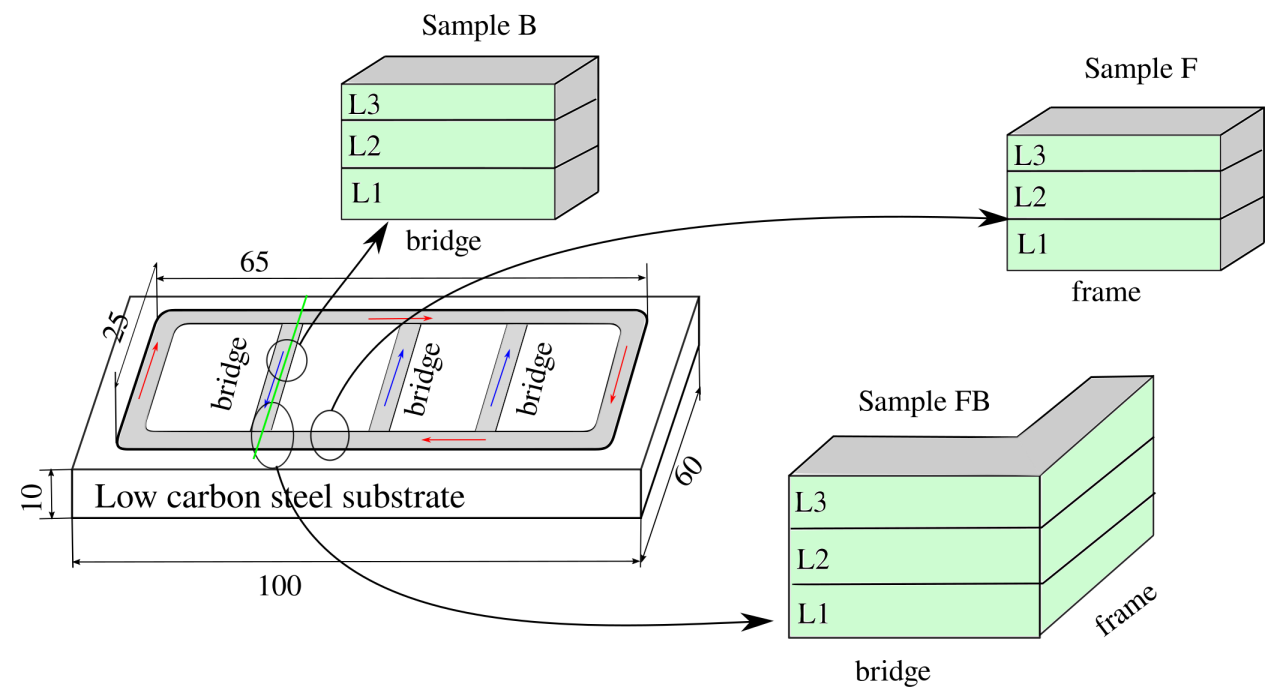

Fig. 1. (Color online) Scheme of the deposition of a 3D frame-bridge sample and elements of the sample where the structure was studied. Within one layer, the frame was deposited first (red arrows) and then the bridges were deposited (blue arrows). The sample was cut along the green line and the structure of the sample was studied from the sides that are colored by green. All sizes are in $\mathrm{mm}$. 
frame was deposited first (red arrows) and then bridges were produced (blue arrows) and this was repeated three times. The sample was cut to two parts along one bridge (a green line in Fig. 1) using an ARTA 153-Pro electro-discharge machine. The surface (shown in Fig. 1 by a light green color) of three elements: frame (Sample F), bridge (Sample B) and frame + bridge (Sample FB) were grinded and polished according to the standard procedure and etched in a solution of $\mathrm{HF}+4 \mathrm{HNO}_{3}+5 \mathrm{H}_{2} \mathrm{O}$ (for 60 seconds at room temperature). Two surfaces were prepared in "Sample FB" that allowed studying the structure of the joint area from the frame and bridge sides as shown in Fig. 1.

The structure of the sample was investigated by light and scanning electron microscopy and by energy dispersive X-ray spectroscopy. The light microscopy (LM) study was carried out using a LOMO METAM 31-LV microscope equipped with a video camera. The scanning electron microscopy (SEM) study was carried out using a Zeiss "Merlin ${ }^{\mathrm{TM}}$ " equipped with an energy dispersive X-ray (EDX) "Oxfords Instruments INCAx-act". The LM and SEM images was analysed by Image Expert Pro software.

\section{Experimental results}

Fig. 2 shows an optical image of Sample F (frame) located far from the joint between the bridge and the frame. It is found that the structure is typical for the samples produced by WAAM [11]. The bottom layer L1 (marked by A) has a complex structure due to the elements of the substrate that penetrate to the melt and affect the structure of the first layer. The second and third layers consist of columnar grains (marked by B) which grow across the layers and have a length of several millimeters and a width of up to $0.1-0.2 \mathrm{~mm}$. On the top of the last layer an equiaxed grain zone (marked by D) is observed. SEM analysis shows that the first layer consists of grains of the NiTi phase (grey areas) with an average grain size of $100 \mu \mathrm{m}$. The black precipitates inside the NiTi grains were TiC particles. The wide light grey areas on the NiTi grain boundaries consisted of $\mathrm{Ni}_{4} \mathrm{Ti}_{3}$ precipitates. $\mathrm{TiC}$ particles are only found in the second and third layers, and the far the layer from the substrate, the less the volume fraction of the precipitates. Fe atoms were found in the NiTi phase and its concentration decreased from $17 \pm 1$ at.\% in the first layer to $2.5 \pm 0.5$ at. $\%$ in the third layer.

Fig. 2 shows the structure of Sample B cut from the bridge far from the joint of the bridge and the frame. It is seen that the structure is close to the structure of Sample F. However, there are some specific features: the columnar grains area B is divided by zone $\mathrm{C}$ which consists of equiaxed grains. The length of columnar grains is smaller than in Sample F. The distribution of the $\mathrm{TiC}$ precipitates and $\mathrm{Fe}$ concentration in the Sample B" were the same as in Sample F.

Fig. 3 shows that the structure of the joint between the bridge and frame (Sample FB) significantly differs from the structure of Samples F and B. The first layer (L1) of Sample FB contains columnar grains that grew across the layer in the sides of both the frame and the bridge. The dark area in the first layer has the same structure as marked by letter A
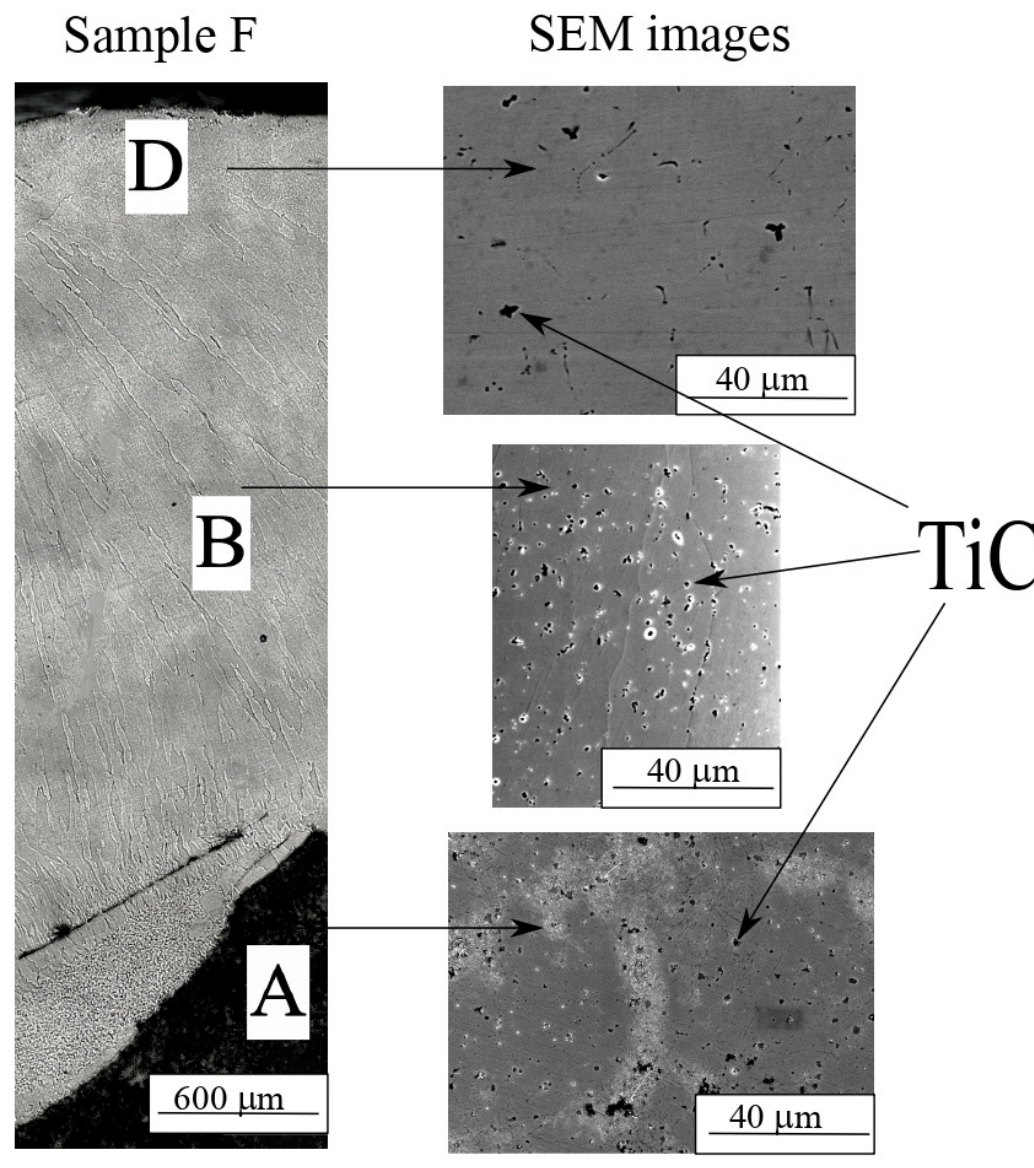
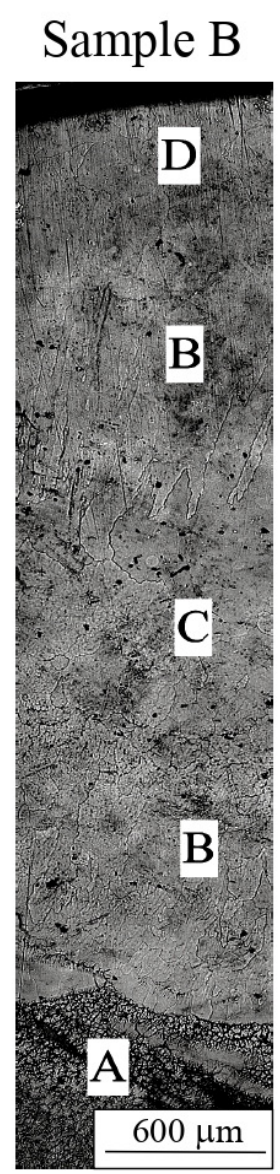

Fig. 2. Optical and SEM images of Sample F and Sample B cut far from the joint between the frame and the bridge. 
in Fig. 2. In the second layer (L2), there are columnar like grains that grew along the frame and are perpendicular to the bridge. Such a structure is found only in the vicinity of the joint. The last layer (L3) contains columnar grains that grew from some point on the top of the layer like a brush.

The results of the study show that far from the joint of the frame and bridges in the 3D frame-bridge sample, the structure of the frame (Sample F) is the same as in the walls. The structure of the bridge (Sample B) far from the joint is close to the structure of the wall but an area of equiaxed grain was found between the columnar grains in the second layer. In the joint of the frame and the bridge (Sample FB), the grain structure is not typical for walls produced by WAAM because the columnar grains form across as well as along the frame.

The formation of grains during deposition of the sample produced by WAAM is determined by the cooling rate and heat absorption [11]. During the deposition of the frame, the heat propagation on cooling occurs along the height of the layers as the cold substrate absorbs heat. In this case, the columnar grains grow across the layers and the structure of Sample F (Fig. 2) is typical for the structure of the "walls" produced by WAAM [11]. During the deposition of the bridge, which is added to the frame, the ways for heat transfer depend on the locations. Far from the joint, the heat is absorbed by the cold substrate and the structure of sample B is close to the structure of Sample F. At the same time, the equiaxed grain zone form in the second and which may be caused by the top area of the second layer was not remelted during the deposition of the third layer. However, an additional study should be carried out to clarify the process of the formation of zone C.

Heat can propagate near the joint to the substrate and along the frame layer, the temperature of which is lower than the temperature of the bridge. During the deposition of the first bridge layer, the heat absorbed by the cold substrate is more effective and the columnar grains form across the bridge layer (Fig. 3). However, when the second bridge layer was deposited, the heat absorption along the frame was more preferable that provided the epitaxial grain growth in this direction (Fig. 3). That is why the cross section of the columnar grains is only visible on the bridge side of Sample FB (Fig. 3). As the columnar grains were formed along the frame and found only in the vicinity of the joint, hence during the deposition of the bridge, some part of the frame was remelted and these grains appeared during the re-solidification. In the last layer, the maximum cooling rate was provided from the free surface of the melt due to the frame and bridge were hot, that was why the columnar grains grew as a brush from the free surface (Fig. 3).

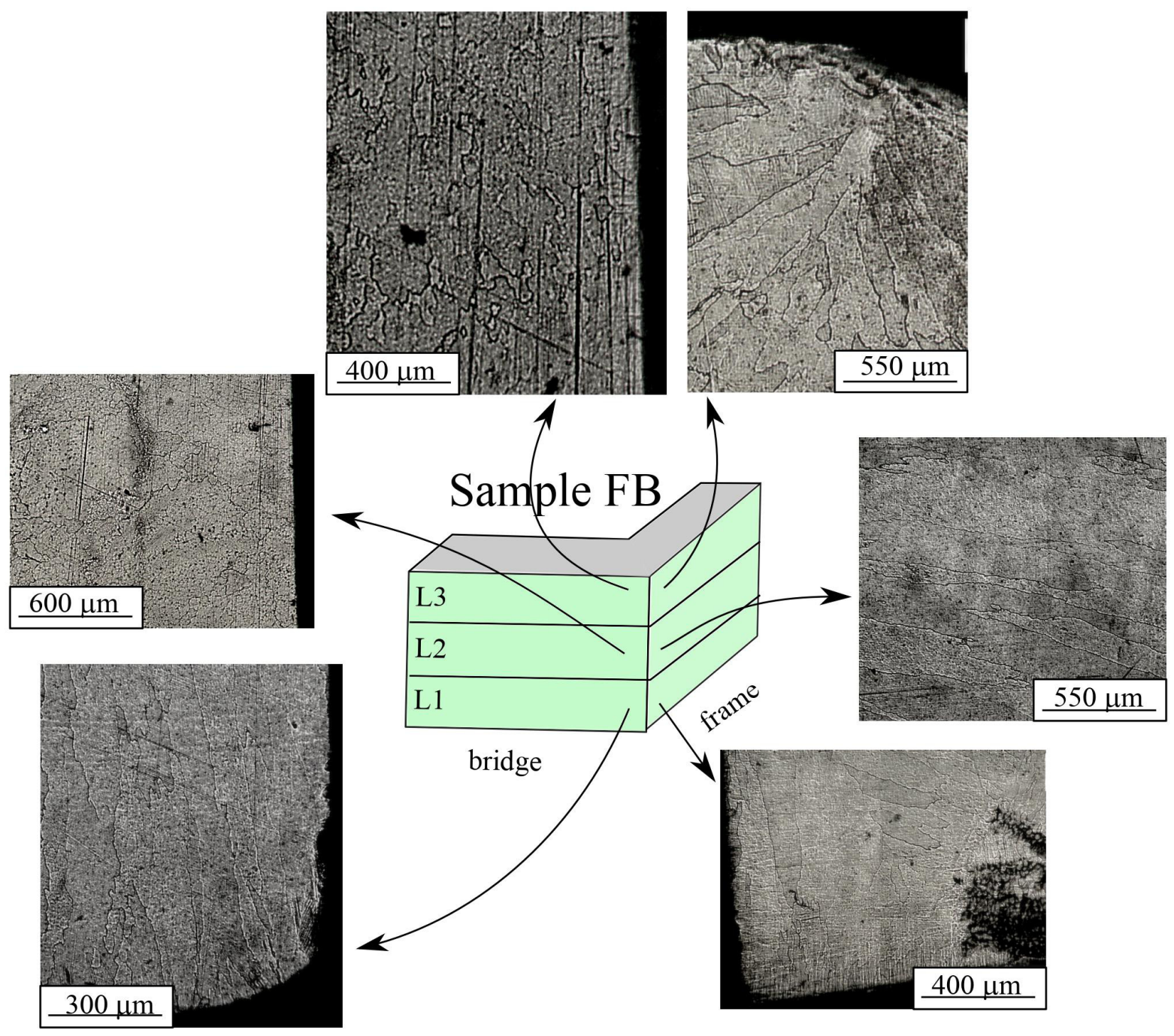

Fig. 3. Optical images of different layers in Sample FB (the joint between the frame and the bridge). 
The concentration of Fe atoms and the distribution of TiC on the sides of both the frame and the bridge of Sample FB were the same as in Samples F and B. Thus, the grain formation in the frame, the bridge and in the joint was different due to different cooling conditions, whereas the processes of Fe and $\mathrm{C}$ diffusion in the NiTi phase and the formation of precipitates were similar. Despite the Fe concentration decreased along the sample height, its value was higher than 1.5 at.\% even in the third layer, which completely suppressed the martensitic transformation. This was confirmed by a calorimetric study, which did not show any peaks during cooling to $-110^{\circ} \mathrm{C}$. Moreover, the existence of $\mathrm{TiC}$ precipitates significantly hardens the sample and depresses the plastic deformation of the sample. During the compression of a frame sample $(2.5 \times 2.5 \times 5 \mathrm{~mm})$ at room temperature on a Lloyd $30 \mathrm{k}$ Plus testing machine using a reverse frame (strain rate of $0.02 \mathrm{~mm} / \mathrm{min}$, compression across the layers), the plastic deformation starts at a stress more than $800 \mathrm{MPa}$.

\section{Conclusions}

Therefore, the results of the study show that the structure of a 3D frame-bridge NiTi sample produced by wire arc additive manufacturing is more complex than the structure of simple "walls". The grain morphology in the frame, the bridges and in the joint of the frame and bridges are different. In vicinity of the joint, columnar grains form both across and along the layers, while far from the joint, they grow across the layers. The $\mathrm{Fe}$ and $\mathrm{C}$ elements diffuse from the low carbon steel substrate during the deposition of the sample that leads to the penetration of Fe atoms in the NiTi phase and to the formation of $\mathrm{TiC}$ precipitates. As the grain structure in different parts of the $3 \mathrm{D}$ frame-bridge sample is different, this should significantly affect the mechanical behaviour of the sample.

Acknowledgements. The study was carried out within joint DST-RSF project (RSF \#19-49-02014, DST
\#DST/INT/RUS/RSF/P-36). The SEM and EDX studies were carried out using the equipment of Resource Centre for Nanotechnology of Saint Petersburg State University.

\section{References}

1. W.E. Frazier. J. Mech. Eng. Perform. 23, 1917 (2014). Crossref

2. T. DebRoy, H.L. Wei, J.S. Zuback, T. Mukherjee, J.W. Elmer, J. O. Milewski, A. M. Beese, A. Wilson-Heid, A. De, W. Zhang. Progress Mater. Sci. 92, 112 (2018). $\underline{\text { Crossref }}$

3. E.V. Melnikov, E.G. Astafurova, S.V. Astafurov, G.G. Maier, V.A. Moskvina, M.Yu. Panchenko, S. V. Fortuna, V.E. Rubtsov, E. A. Kolubaev. Letter on Materials. 9 (4), 460 (2019). Crossref

4. K. Otsuka, X. Ren. Progress Mater. Sci. 50, 511 (2005). Crossref

5. A. I. Razov. Phys. Met. Metal. 97, 97 (2004).

6. V. Brailovski, F. Trochu. Bio-Medical Materials and Engineering. 6, 291 (1996). Crossref

7. L. Petrini, F. Migliavacca. Journal of Metallurgy. 2011, 501483 (2011). Crossref

8. M. Elahinia, N.S. Moghaddam, M.T. Andani, A. Amerinatanzi, B. A. Bimber, R.F. Hamilton.Progress Mater. Sci. 83, 630 (2016). Crossref

9. S. Vock, B. Klöden, A. Kirchner, T. Weißgärber, B. Kieback. Prog. Addit. Manuf. 4, 383 (2019). Crossref

10. H. Taheri, L. Koester, T. Bigelow, P.C. Collins. J Addit Subtractive Mater Manuf. 2, 172 (2017). Crossref

11. B. Wu, Z. Pan, D. Ding, D. Cuiuri, H. Li, J. Xu, J. Norrish. J Manuf. Proces. 35, 127 (2018). Crossref

12. J. Wang, Z. Pan, G. Yang, J. Han, X. Chen, H. Li.Mater. Sci. Eng. A. 749, 218 (2019). Crossref

13. Z. Zeng, B. Q Cong, J.P. Oliveira, W. C Ke, N. Schell, B. Peng, Z. W. Qi, F. G Ge, W. Zhang, S. S. Ao. Additive manuf. 32, 101051 (2020). $\underline{\text { Crossref }}$ 